\title{
Perception of Work-Life Balance among Married Female Librarians in University Libraries in South-East Nigeria
}

\author{
Ijeoma J. Ibegbulam and Anthonia N. Ejikeme
}

\begin{abstract}
This survey study discusses the perception of work-life balance among married female academic librarians in university libraries in South-East Nigeria. Purposive sampling technique was used to select 90 married female academic librarians from a population of 150 female academic librarians working in the university libraries. The study examines the perception of family and organizational factors of work-life balance among the respondents. The results reveal that the married female academic librarians have a positive perception of family and organizational factors of work-life balance; however, perception of the organizational factor has a slightly higher mean score than the family factor. The study highlights strategies that could enhance work-life balance among the respondents and recommends the implementation of practices and policies such as flexible work schedule, cancellation of overtime and shift duties, and better remuneration to improve work-life balance among academic librarians.
\end{abstract}

\section{Introduction}

Generally speaking, married working females experience a considerable amount of strain as a result of the multiple roles they play as wives who may have children and obligations to their homes as well as employees who have obligations to their employers. For instance, in a typical Nigerian home, the married working female is still expected to cook, clean, and take care of the children, husband, and (in some cases) elderly dependents. Some weekends, she may be required to accompany her husband to extended family events such as meetings, weddings, and/or funerals, all irrespective of place, type, terms, and conditions of employment. ${ }^{1}$ In the event of a conflict between the work demands and the family demands, the married working female is expected to prioritize her family over her paid employment because employment is rarely regarded as a cogent reason to shirk family responsibilities. ${ }^{2}$ At her workplace, she is expected to perform her job the same way as her single female and male colleagues, also irrespective of her family commitments and/or obligations. Just as happens in the home, failure to meet expectations in the workplace could result in some unpleasant outcomes to her.

\footnotetext{
*Ijeoma J. Ibegbulam is Principal Librarian in the Medical Library, College of Medicine, University of Nigeria, Ituku/Ozalla Campus; email: ijeoma.ibegbulam@unn.edu.ng. Anthonia N. Ejikeme (corresponding author) is Principal Librarian in the Nnamdi Azikiwe Library, University of Nigeria, Nsukka; email: anthonia.ejikeme@unn.edu. ng. @2021 Ijeoma J. Ibegbulam and Anthonia N. Ejikeme, Attribution-NonCommercial (https://creativecommons. org/licenses/by-nc/4.0/) CC BY-NC.
} 
The expectation is no different for married female academic librarians, as they have to juggle the demands of their paid employment with that of their homes. In Nigerian universities, the situation of married female academic librarians is further compounded by the fact that, as academic staff, in addition to their regular everyday library job activities, academic librarians, like the teaching faculty members, are required to engage in research and publishing and also pursue postgraduate studies up to the $\mathrm{PhD}$. Academics must be successful in these requirements or stand the risk of frustration and/or career stagnation. ${ }^{3}$

However, while this expectation is general to all academic staff, it is a little harder for married female librarians to meet because the single female librarians may not have the added family obligations that the married female grapples with. In the same vein, although the male colleagues (librarians and faculty members) may have some of their own issues to deal with-given that work-life conflict is not gender-specific - it has been found that "men tend to be more likely to be able to balance work and home life because the societal expectations place the burden of domestic duties and parenting mostly on women."

Furthermore, although "academic librarians and teaching faculty both face work related stressors that may lead to low levels of job satisfaction, lack of motivation, and decreased retention," 5 academic librarians' experiences are "unique because they often do not benefit from the same independence and autonomy in their work schedules as many teaching faculty members do." 6 This is because, unlike the faculty members, "many librarians work a standard forty hour work week, and are kept busy with running the daily activities of libraries." As for the married female teaching faculty, the flexibility that is inherent in teaching-faculty positions also allows them to balance both work and family better. ${ }^{8}$

To buttress the foregoing, academic librarians in Nigeria report to work as early as 8:00 in the morning and close at 4:00 in the afternoon (Monday through Friday), while the teaching faculties come to school mostly when they have classes or some other official activities to take care of, after which they are free to leave. Additionally, academic librarians from the status of Librarian II to Senior Librarian are often required to work shift, weekend, or overtime duties, irrespective of their marital status. When a married woman is rostered for these duties, it further reduces the time that she spends at home. This inflexibility of academic librarians' schedule is compounded by the fact that there is minimal provision for family responsive policies in place in the country. ${ }^{9}$ Given all this, it is not inconceivable that family-work-workfamily conflict may arise.

Family-work conflict (FWC) is a role conflict in which work roles interfere with family roles, while work-family conflict (WFC) is a role conflict in which the family roles interfere with the work roles. ${ }^{10}$ FWC and WFC are more likely to exert negative influences in the family domain, resulting in lower life satisfaction and greater internal conflict within the family. ${ }^{11}$ Work-life balance is defined as "a state where an individual manages real or potential conflicts between different demands on his or her time, and energy in a way that satisfies his or her needs for well-being and self-fulfilment."12 Because individuals have a work life and a personal life, work-life balance is the relationship attained between work that an individual is being paid for and the lives individuals live outside their paid employment. ${ }^{13}$ It should be noted that worklife balance does not imply equal balance in a person's several roles; but, where it is achieved, it helps to ensure that "work roles and family commitments are arranged in the most realistic and rewarding ways that can best meet the two fundamental needs." ${ }^{14}$ Thus, work-life balance suggests a satisfactory level of involvement or fit between the multiple roles in a person's life 
since there cannot be an absolute balance. ${ }^{15}$ Work-life balance of employees is important because of its broader relationship with quality of life, ${ }^{16}$ given that a "person whose various dimensions are harmoniously attuned will be more effective in his/her working environment." 17 The implication is that any university library that desires to succeed in its organizational objectives must deliberately cultivate work-life balance among their employees.

This study is important for several reasons: first, given that librarianship is a female-dominated profession, women are the primary providers of library services to users. ${ }^{18}$ Therefore, their positive perception of work-life balance is important for organizational success. Second, the concept of work-life balance is underrepresented in library literature. ${ }^{19}$ To this end, this study represents an attempt to close this gap, and so the findings of this study are expected to be useful for human resource management in libraries as well as contribute to the literature.

\section{Research Questions}

This study was guided by the following research questions:

- RQ1: What is the perception of work-life balance at the family level among married female academic librarians in South-East Nigeria?

- RQ2: What is the perception of work-life balance at the organizational level among married female academic librarians in South-East Nigeria?

- RQ3: What strategies can enhance work-life balance among married female academic librarians in South-East Nigeria?

\section{Literature Review}

Work-life balance has been described as a broad topic that overlaps many human resources issues, such as recruitment, retention, advancement, turnover, job satisfaction, and employee motivation; to that extent, it cuts across all disciplines. ${ }^{20}$ The concept of work-life balance of women is receiving a rising interest among researchers today because many women are pursuing jobs and careers while having families. ${ }^{21}$ The practice of women pursuing jobs and careers while having families is a departure from the common occurrence across many countries that men worked outside the home to earn money and, for husbands, with which to support the family while women marry and stay home to tend the house, cook and clean and raise the children. This changing trend is experienced even in more traditional societies because, as more women go to school and obtain certificates, coupled with economic and other pressures of modern society, many now work outside the home for their own fulfillment and to improve the economic status of their families.

While working outside the home has given married women some economic and social leverage and with it, a measure of independence, it has nonetheless come with some challenges. For instance, although the married working woman may be saddled with responsibilities such as care of the husband and infant children, among other responsibilities in the home, she still has obligations to her workplace, as her employer also expects her to perform her professional roles satisfactorily amid constraints such as work overload, inflexible working hours, uncooperative supervisors, and other organizational issues. ${ }^{22}$

The implication of family and workplace demands is that it increases the likelihood that women employees will experience conflict between their work and family roles thus contribute to higher levels of work-family conflict (WFC). ${ }^{23}$ In most cases, married women's work demand places more negative influence on the family responsibilities than the family demand places 
on the work. ${ }^{24}$ Family-work-conflict (FWC) or WFC can negatively impact the quality of life of the woman because they basically result from an individual trying to meet an overabundance of conflicting demands from the different domains in which they are operating. ${ }^{25}$ The reason women appear to experience more conflict than men, however, is because work-life balance is "seen more as women [sic] issue due to the traditional mindset, where the woman is considered primarily responsible for the smooth running of the day to day affairs of the family irrespective of her job profile and official responsibilities." ${ }^{26}$

Work-life balance of employees should concern organizations because it has been found that, when employees achieve work-life balance, it leads to a feeling of fulfillment and satisfaction inside and outside of work, making it possible for the employees to experience minimal conflict between their work and nonwork roles. ${ }^{27}$ Also, a positive correlation is found to exist between work-life balance and increased organizational performance, because a satisfied employee is more able to cope on both the professional and personal levels, thereby enhancing employee efficiency in the workplace. ${ }^{28}$ This is hardly surprising, because personal success is necessary for workplace success.

On the other hand, inability to achieve work-life balance usually results in some major consequences, including high levels of stress and anxiety, disharmony at home, job burnout, and inability to realize full potential. ${ }^{29}$ Other negative outcomes associated with work-life imbalance include stress, physical problems, relational problems, hangover, unethical practices, disturbed families, decreased performance, and organizational jeopardy. ${ }^{30}$ The individual feels irritable and resentful, and this can affect productivity in the family and workplace. In fact, balancing job demands and household tasks, including household and childcare demands, have been documented as a huge barrier that prevents women from reaching their full potentials. ${ }^{31}$ To mitigate this, many employees including women may resort to unethical practice such as abandoning their duty post during working hours to run errands for personal gains, thus heightening the issue of inefficiency, ineffectiveness, and low productivity in the workplace. ${ }^{32}$

Some empirical studies carried out on work-life balance in library and nonlibrary settings have made some interesting findings. While the studies conducted in libraries did not focus solely on married female academic librarians, they nonetheless give us an insight into the perception of work-life balance in the library environment. A study to ascertain the demographic determinants of quality of work-life of librarians working in various libraries in Nigeria revealed a relatively high quality of work life in the areas of opportunity for continued growth and security, social integration in the work organization, and social relevance of work. However, important areas such as fair remuneration, training and retraining, provision for job performance, and equal rights issues were areas of dissatisfaction for the librarians. ${ }^{33}$

Another study conducted in Ghana, West Africa, explored the influence of work-life balance on employee commitment of social workers. The results showed that unmarried employees balanced their work and family roles better than their married counterparts. Women also experienced more work-life conflict than men. A weak positive relationship existed between work-life balance and commitment among employees because they were not satisfied with paternity leave, study leave, and part-time work. ${ }^{34}$

Elsewhere, in the United States, a study investigated the impact of faculty status and gender on employee well-being in academic libraries; it measured job satisfaction, personal fulfillment, work-life balance, and stress levels of male and female librarians. The results 
revealed that females at libraries offering faculty status indicated poor work-life balance and high levels of stress compared to male colleagues and female librarians without faculty status; however, the reported job satisfaction of both male and female librarians was similar. ${ }^{35}$

Another study also carried out in the United States focused on policy implications of putting work-life into practice for academic librarians. The respondents perceived workplace barriers to achieving an ideal work-life balance to include workload, institutional policies, schedule inflexibility, uncooperative management, and concerns about career success and recognition. However, despite the barriers, a majority of the respondents reported that they would not consider leaving the profession as a whole to achieve greater work-life balance. Also, most of the respondents felt that they were compensated adequately for their work. The respondents also reported that they used a variety of workplace strategies to achieve work-life balance. The most popular of the strategies was flexible scheduling, and the least popular was sabbatical. When it came to work-life balance outside the workplace, they relied on a partner or spouse for support and friends to maximize work-life balance. ${ }^{36}$

In India, an analysis of the perception of work-life balance among female employees in the IT sector revealed that the married female respondents were affected by job activities at the workplace and responsibilities at home, while the unmarried and divorced female employees were less affected by these types of activities. ${ }^{37}$ In China, a positive relationship was found between work-life balance and level of job and income of women workers. The findings revealed that employees who hold higher posts in organizations and earned higher salaries experienced greater work pressure, which in turn affected their families negatively. On the other hand, employees with lesser incomes struggled with work-life issues because they could not hire paid assistance to help with work and family responsibilities. Furthermore, women with lower income gave more priority to the family, while women with higher income focused to a greater extent on their career growth. ${ }^{38}$ This finding about the lower-income earners seems to suggest that, beyond a heavy workload, a major obstacle to married women's work-life balance is income inadequacy or the absence of money needed to perform one's role better.

Demographic variables such as number of children, age of eldest child, and educational qualification were studied..$^{39}$ Another demographic variable said to influence work-life balance is gender, and another study found that work-family conflict and family-work conflict was higher among women whose eldest child is between 7 and 10 years old. ${ }^{40}$

To ameliorate the conflicts that arise from work-life imbalance, some strategies have been advanced. Here are some of those strategies: (1) employers should introduce (where they do not already exist) or strengthen already existing work-life balance practices to enable their married female employees to experience less conflict in the family and workplace; ${ }^{41}(2)$ introduction of flexible work hours (since flexibility at the workplace has been found to have a positive impact on employees' well-being and work-life balance, resulting in higher job satisfaction, higher home activity satisfaction, and lower conflict); ${ }^{42}$ (3) short work week; (4) job sharing; (5) family leave programs; and (6) onsite childcare and financial rewards. ${ }^{43}$ Family support and outsourcing of housework are also good strategies for work-life balance as found in the cross-culture study conducted in India ${ }^{44}$ and the United States. ${ }^{45}$

From the foregoing, it can be seen that four types of variables relate to work-life balance: (1) family variables; (2) organizational (workplace) variables; (3) personal variables; and (4) social variables. This study will, from the point of view of the respondents, concentrate on the family variables and organizational (workplace) variables. 


\section{Methodology}

The study employed a descriptive survey design. Purposive total sampling technique was used to draw a population consisting of 150 female academic librarians from among employees who worked in the following four university libraries in South-East Nigeria: University of Nigeria Nsukka; Odumegwu Ojukwu University; Ulli, Federal University of Technology, Owerri; and Michael Okpara University, Umudike. From this population, 90 married female librarians were further purposively sampled. The instrument for data collection was a questionnaire which the researchers adapted from the literature. ${ }^{46}$ Some of the questions were rephrased to reflect the local context and to also aid understanding. The questionnaire was in four sections. Section A covered the demographics of the respondents. Section B of the questionnaire focused on the family factor level of work-life balance, while Section C covered items on the organizational factor level of work-life balance. Last, Section D was on the strategies that could be employed to improve on work-life balance of female academic librarians. The questions were all positively worded to avoid misunderstanding and mistakes by respondents, as well as miscoding during analysis. To elicit responses, the items in Section B to D were ranked on a four-point scale. The responses were scored quantitatively using Strongly Agree, Agree, Disagree, and Strongly Disagree, to which real limits of numbers $-4,3,2,1$-were assigned respectively. A face/ content validity test carried out on the instrument yielded .92 on the Cronbach Alpha Coefficient test. The Cronbach Alpha Coefficient developed by Lee Cronbach in 1951 is used to measure the reliability or internal consistency of a test or scale. Internal consistency describes the extent to which all the items in a test measure the same concept or construct. ${ }^{47}$ Because it was not mandatory to obtain ethical clearance, a covering note was attached to the questionnaire to explain the purpose of the research, and to also solicit the cooperation of the respondents. The covering note assured respondents of the confidentiality of their responses.

Copies of the questionnaire were distributed to the female academic librarians at the University of Nigeria, Nsukka, including the Enugu Campus of the university, and collected by the researchers. For the populations at the three universities, the researchers relied on the assistance of three colleagues, one from each of the universities. The three colleagues were carefully put through the questionnaire to get them to understand the requirements. A total of 90 questionnaires were distributed, while $73(81 \%)$ were returned.

The Statistical Package for the Social Sciences (SPSS) was used for data analyses.

Descriptive statistics was used to analyze the demographic data and the research questions. The criterion mean for the descriptive statistics was set at 2.50. Therefore, a mean score of 2.50 and above indicated agreement with the statement as it affected the family factor and/ or organizational factor variables of the study.

\section{Data Analysis}

\section{Demographics}

Data analysis was based on $73(81 \%)$ returned questionnaires. Figure 1 presents the demographic information of respondents. The figure shows that the majority of respondents $(45.2 \%$, $\mathrm{n}=33)$ fall within the age range of 30-40. In terms of length of marriage, the majority (42.5\%, $\mathrm{n}=31)$ have been married for 11-20 years. Finally, the majority of respondents $(42.5 \%, \mathrm{n}=31)$ have children aged 11-20. 




Research Question 1: What is married female academic librarians' perception of work-life balance at the family factor level?

Results in table 1 show the mean ratings and standard deviation of respondents on the perception of work-life balance at the family level. The results of the analysis show that the perception of work-life balance in the family environment among married female academic librarians is positive, with an overall mean of 2.51. However, a close look at the individual items on the family level shows that the statement with the highest mean score $(\mathrm{M}=3.10)$ is "I have many dependents who look to me for assistance." Also, the respondents disagreed 


\begin{tabular}{|c|c|c|c|c|c|c|c|c|c|c|c|c|}
\hline \multicolumn{13}{|c|}{$\begin{array}{c}\text { TABLE } 1 \\
\begin{array}{c}\text { Mean and Standard Deviation of Responses on the Perception of Work-Life Balance } \\
\text { Practices on the Family Factor Level }\end{array}\end{array}$} \\
\hline \multirow[t]{2}{*}{$\mathbf{S} / \mathbf{N}$} & \multirow[t]{2}{*}{ Items } & \multicolumn{2}{|c|}{ Below 30} & \multicolumn{2}{|c|}{$\begin{array}{l}30-40 \\
\text { Years }\end{array}$} & \multicolumn{2}{|c|}{$\begin{array}{l}41-50 \\
\text { Years }\end{array}$} & \multicolumn{2}{|c|}{$\begin{array}{c}\text { Above } 50 \\
\text { Years }\end{array}$} & \multicolumn{2}{|c|}{ Overall } & \multirow[b]{2}{*}{ Dec. } \\
\hline & & $\bar{x}$ & SD & $\bar{x}$ & SD & $\bar{x}$ & SD & $\bar{x}$ & SD & $\bar{x}$ & SD & \\
\hline 1 & $\begin{array}{l}\text { My husband shares house } \\
\text { hold chores equally with } \\
\text { me }\end{array}$ & 2.10 & 1.02 & 2.26 & 1.06 & 2.12 & 1.05 & 2.60 & 0.89 & 2.21 & 1.02 & $\mathrm{D}$ \\
\hline 2 & $\begin{array}{l}\text { My husband helps with } \\
\text { taking the children to } \\
\text { school }\end{array}$ & 2.95 & 0.68 & 2.61 & 0.71 & 2.94 & 0.74 & 2.80 & 0.44 & 2.79 & 0.70 & $A$ \\
\hline 3 & $\begin{array}{l}\text { My husband helps with } \\
\text { the children's home work }\end{array}$ & 2.65 & 0.74 & 2.71 & 0.64 & 2.65 & 0.78 & 3.00 & 0.00 & 2.70 & 0.68 & $A$ \\
\hline 4 & $\begin{array}{l}\text { My husband helps with } \\
\text { shopping }\end{array}$ & 2.70 & 0.65 & 2.45 & 0.67 & 2.65 & 0.60 & 2.80 & 0.83 & 2.59 & 0.66 & $A$ \\
\hline 5 & $\begin{array}{l}\text { My grown up children } \\
\text { assist with house chores }\end{array}$ & 2.75 & 0.63 & 2.84 & 0.52 & 2.76 & 0.66 & 2.80 & 0.44 & 2.79 & 0.57 & $A$ \\
\hline 6 & $\begin{array}{l}\text { The family income is } \\
\text { sufficient for our needs }\end{array}$ & 1.85 & 0.98 & 1.90 & 1.01 & 2.35 & 0.70 & 2.00 & .00 & 2.00 & 0.91 & D \\
\hline 7 & $\begin{array}{l}\text { I have labor saving devices } \\
\text { at home }\end{array}$ & 2.05 & 0.94 & 1.97 & 0.94 & 2.29 & 0.58 & 2.40 & 0.89 & 2.10 & 0.86 & $D$ \\
\hline 8 & $\begin{array}{l}\text { I enjoy the services of a } \\
\text { house help at home }\end{array}$ & 2.40 & 1.35 & 2.68 & 1.01 & 2.82 & 0.95 & 2.80 & 0.83 & 2.64 & 1.08 & D \\
\hline 9 & $\begin{array}{l}\text { I have many dependents } \\
\text { that look up to me for } \\
\text { assistance }\end{array}$ & 3.10 & 0.44 & 2.71 & 0.73 & 2.53 & 0.80 & 2.40 & 0.54 & 2.75 & 0.70 & $A$ \\
\hline 10 & $\begin{array}{l}\text { My in-laws are friendly } \\
\text { towards me }\end{array}$ & 3.05 & 0.51 & 2.68 & 0.74 & 2.41 & 0.71 & 2.40 & 0.89 & 2.70 & 0.72 & $A$ \\
\hline 11 & $\begin{array}{l}\text { I have a personal car for } \\
\text { work and errands }\end{array}$ & 3.00 & 0.72 & 2.84 & 0.73 & 2.65 & 0.93 & 2.40 & 0.54 & 2.81 & 0.77 & A \\
\hline 12 & $\begin{array}{l}\text { I engage laundry services } \\
\text { for washing family clothes }\end{array}$ & 1.90 & 1.16 & 2.16 & 0.93 & 2.35 & 0.78 & 2.00 & 0.00 & 2.12 & 0.94 & D \\
\hline & Cluster Mean & 2.54 & 0.50 & 2.48 & 0.51 & 2.54 & 0.53 & 2.53 & 0.30 & 2.51 & 0.49 & A \\
\hline
\end{tabular}

with the following statements: "The family income is sufficient for our needs" $(M=1.85)$, "I engage laundry services for washing family clothes" $(\mathrm{M}=1.90)$, "I have labor-saving devices at home" $(\mathrm{M}=2.05)$, "My husband shares household chores equally with me" $(\mathrm{M}=$ $2.10)$, and "I enjoy the services of a house help at home" $(\mathrm{M}=2.40)$. The individual cluster mean shows that those within the age range of 30-40 years scored the lowest (2.48), while those younger than 30 years and 41-50 years scored the highest, with mean score of 2.54 respectively.

Research Question 2: What is married female academic librarians' perception of work-life balance in the organizational level? 


\begin{tabular}{|c|c|c|c|c|c|c|c|c|c|c|c|}
\hline Me & and Standard Deviation of & $\begin{array}{l}\text { Resp } \\
\text { gani }\end{array}$ & $\begin{array}{l}\text { TAB } \\
\text { ses } \\
\text { iona }\end{array}$ & $\begin{array}{l}\text { E } 2 \\
\text { th } \\
\text { Fac }\end{array}$ & er & el & f & k & $\mathbf{P}$ & & the \\
\hline $\mathbf{S} / \mathbf{N}$ & Items & $\begin{array}{r}\text { Belc } \\
\text { Ye }\end{array}$ & $\begin{array}{l}\text { w } 10 \\
\text { ars }\end{array}$ & & $\begin{array}{l}-20 \\
\text { ars }\end{array}$ & & & & $\begin{array}{l}\text { and } \\
\text { ove }\end{array}$ & Ove & erall \\
\hline & & $\overline{\bar{x}}$ & SD & $\bar{X}$ & SD & $\overline{\bar{X}}$ & SD & $\overline{\bar{X}}$ & SD & $\overline{\bar{X}}$ & SD \\
\hline 1 & $\begin{array}{l}\text { I have an understanding top } \\
\text { management }\end{array}$ & 4.00 & 0.00 & 2.61 & 1.24 & 2.88 & 0.99 & 2.62 & 0.96 & 2.75 & 1.11 \\
\hline 2 & $\begin{array}{l}\text { My immediate supervisor is } \\
\text { considerate towards me }\end{array}$ & 2.67 & 1.15 & 2.73 & 0.62 & 2.33 & 0.56 & 2.23 & 0.59 & 2.51 & 0.64 \\
\hline 3 & My co-workers are cooperative & 3.00 & 1.00 & 2.85 & 0.61 & 2.67 & 0.76 & 2.23 & 0.59 & 2.68 & 0.70 \\
\hline 4 & My working hours are flexible & 3.33 & 0.57 & 2.94 & 0.55 & 2.83 & 0.63 & 2.08 & 0.27 & 2.77 & 0.63 \\
\hline 5 & $\begin{array}{l}\text { There is close proximity from my } \\
\text { house to my work location }\end{array}$ & 2.00 & 1.73 & 2.06 & 1.08 & 2.08 & 0.88 & 2.15 & 0.55 & 2.08 & 0.95 \\
\hline 6 & We share jobs in the office & 3.67 & 0.57 & 3.39 & 0.49 & 3.29 & 0.46 & 3.23 & 0.43 & 3.34 & 0.47 \\
\hline 7 & My work load is reasonable & 3.67 & 0.57 & 3.33 & 0.47 & 3.46 & 0.50 & 3.38 & 0.50 & 3.40 & 0.49 \\
\hline 8 & I receive adequate remuneration & 1.67 & 1.15 & 1.97 & 1.01 & 2.33 & 0.96 & 2.08 & 1.03 & 2.10 & 1.00 \\
\hline 9 & $\begin{array}{l}\text { There is provision for annual/ } \\
\text { causal leave }\end{array}$ & 3.67 & 0.57 & 3.70 & 0.46 & 3.42 & 0.65 & 3.00 & 0.57 & 3.48 & 0.60 \\
\hline 10 & $\begin{array}{l}\text { There is provision for paid study } \\
\text { leave }\end{array}$ & 2.00 & 0.00 & 2.45 & 0.50 & 2.38 & 0.49 & 2.54 & 0.51 & 2.42 & 0.49 \\
\hline 11 & $\begin{array}{l}\text { I am allowed to phone in sick } \\
\text { when I or a family member is } \\
\text { sick }\end{array}$ & 3.33 & 0.57 & 3.42 & 0.50 & 2.71 & 0.46 & 2.92 & 0.27 & 3.10 & 0.55 \\
\hline 12 & $\begin{array}{l}\text { Over time duties interfere with } \\
\text { my family needs. }\end{array}$ & 3.00 & 0.00 & 3.27 & 0.45 & 2.88 & 0.33 & 2.77 & 0.43 & 3.04 & 0.45 \\
\hline 13 & $\begin{array}{l}\text { Shift duties interfere with my } \\
\text { family needs }\end{array}$ & 3.00 & 0.00 & 3.27 & 0.45 & 3.25 & 0.44 & 3.08 & 0.27 & 3.22 & 0.41 \\
\hline 14 & $\begin{array}{l}\text { Maternity leave period is } \\
\text { adequate }\end{array}$ & 3.67 & 0.57 & 3.48 & 0.50 & 3.38 & 0.49 & 3.08 & 0.27 & 3.38 & 0.49 \\
\hline & Cluster Mean & \begin{tabular}{|l|}
3.04 \\
\end{tabular} & 0.36 & 2.96 & 0.20 & 2.84 & 0.20 & 2.67 & 0.14 & 2.87 & 0.22 \\
\hline
\end{tabular}

Results in table 2 show the mean ratings and standard deviation of respondents on the perception of work-life balance in the library work environment. The overall mean score of 2.87 indicates that the perception of work-life balance in the library work environment among married female academic librarians is positive. This is because the overall mean of 2.87 is above the criterion mean of 2.50. Looking at the individual statements in the table, the statements "I receive adequate remuneration" $(\mathrm{M}=1.67)$ and "There is provision for paid study leave" ( $M=2.00)$ scored the lowest respectively, suggesting dissatisfaction. However, because the items are all positively worded, a high score on any of the individual statements may not necessarily indicate satisfaction with that statement. This can be seen from the statements "Overtime duties interfere with my family needs" and "Shift duties interfere with my family needs" with mean score of 3.00 respectively. It is instructive to note that the table also shows that the married female academic librarians younger than the age of 30 appear to have a higher positive perception of work-life balance on the organizational factor level $(M=3.04)$. 
The individual cluster mean shows that those younger than 30 years of age scored the highest mean (3.04), while those within the age range of 30-40 years follow with mean score of 2.96 .

Research Question 3: What are the strategies that can enhance married female librarians' work-life balance?

\begin{tabular}{|c|c|c|c|c|}
\hline \multicolumn{5}{|c|}{$\begin{array}{c}\text { TABLE } 3 \\
\text { Mean and Standard Deviation on the Strategies to Enhance Work-Life Balance among } \\
\text { Female Academic Librarians }\end{array}$} \\
\hline $\mathbf{S} / \mathbf{N}$ & Items & $\bar{x}$ & SD & Dec. \\
\hline 1 & More support from spouse & 3.05 & 0.74 & A \\
\hline 2 & More assistance from grown up children & 2.74 & 0.74 & A \\
\hline 3 & Engagement of house help & 2.67 & 0.74 & A \\
\hline 4 & Engagement of a driver & 2.89 & 0.79 & A \\
\hline 5 & Use of laundry services for clothes washing & 2.66 & 0.58 & A \\
\hline 6 & Less dependants & 2.79 & 0.40 & A \\
\hline 7 & $\begin{array}{l}\text { Acquisition of labor saving devices for home (laundry machine, } \\
\text { freezer, etc) }\end{array}$ & 2.84 & 0.57 & A \\
\hline 8 & Weekly bulk cooking & 2.85 & 0.66 & A \\
\hline 9 & Monthly bulk shopping & 2.85 & 0.66 & A \\
\hline 10 & More management support & 2.82 & 0.63 & A \\
\hline 11 & More co-operation from co-workers & 2.86 & 0.56 & A \\
\hline 12 & Introduction of flexible office working hours & 2.88 & 0.52 & A \\
\hline 13 & Living at close proximity to work location & 3.01 & 0.54 & A \\
\hline 14 & Cancellation of overtime duties & 2.99 & 0.54 & A \\
\hline 15 & Cancellation of shift duties & 3.08 & 0.68 & A \\
\hline 16 & Extended maternity leave & 2.96 & 0.63 & A \\
\hline \multirow[t]{2}{*}{17} & Granting of paid annual and other leaves & 2.92 & 0.66 & A \\
\hline & Cluster Mean & 2.87 & 0.27 & A \\
\hline
\end{tabular}

Results in table 3 show the mean ratings and standard deviation of respondents on the strategies that can enhance married female librarians' work-life balance. The analyses show that both the individual items and overall mean ratings are above the criterion mean of 2.50. This implies that the respondents see all the items on table 3 as effective strategies that can enhance work-life balance. From the table one can also see that cancellation of shift duties, with a mean rating of 3.08, is perceived as the best strategy, followed by more support from husband $(M=3.04)$ and living at close proximity to the work location $(M=3.01)$.

\section{Discussion}

The findings reveal that, while the married female academic librarians have a positive perception of work-life balance at the family level, this is only minimally. This could be inferred from the fact that, although the total mean score is above the criterion mean score, it is not sufficiently high enough to conclude that the women are very satisfied with work-life balance 
at the family level. This moderate mean score may not be unconnected with the fact that in Nigeria, as in most traditional societies, the woman is saddled with most of the house chores. This supports the assertion that work-life balance is seen more as a woman's issue due to the traditional mindset, where the woman is considered primarily responsible for the smooth running of the day-to-day affairs of the family irrespective of her job profile and official responsibilities, which affects the work-life balance of married working females. ${ }^{48}$ The results also show that insufficient family income is another factor that negatively affects work-life balance among the women. This can be inferred from the fact that underlying some of the responses is income inadequacy. This is likely the reason why some of the women could not procure labor-saving machines or human help to assist them in managing some of their chores. This finding agrees with the finding of a previous study that librarians were not satisfied with their remuneration. ${ }^{49}$ Also, the study among Chinese working women revealed that a major obstacle to work-life balance among the lower income-earning workers was income inadequacy, although this was contradicted by the report of the upper women executives in the same study, who reported time inadequacy rather than money as a major constraint to their work-life balance.

Another interesting finding is that women below the age of 30 seem to have a more positive perception of work-life balance at the family level compared with those of other ages. This is rather surprising, given that this is the most productive and engaging period of a woman's life in terms of child bearing/rearing. It is expected that women below the age of 30 most likely will have young children below the age of 10. If this is the case, the finding that work-conflict and family-work conflict is higher among women whose eldest child is between 7 and 10 years old is contradictory. ${ }^{50}$ On the other hand, the reason for this contradiction could be the very small number of respondents (3) in this category.

At the organizational factors level, the results indicate that the married female academic librarians have a higher positive perception of work-life balance here than they do at the family level, suggesting that family demands exert more negative influence on the women's work-life balance than does the organization. This is contrary to an earlier finding that, in most instances, married women's work demand places more negative influence on the family responsibilities than the family demand places on the work. ${ }^{51}$ However, the higher positive perception of work-life balance at the organizational level could be attributed to the fact that, while there is minimal provision for family-responsive policies in place in the country, ${ }^{52}$ most workers in public institutions/organizations in the country often take some time off during the working hours to run family/personal errands. This could be with the consent of their workmates or, in some cases, the immediate supervisor who in such circumstances gets other individuals to "cover" for the staff in question. While this is done to assist the individual, there is no doubt that the camaraderie that exists in the office that aids individuals to cut into office hours results to decreased organizational performance and productivity. ${ }^{53}$ Abandonment of duty post during office working hours for personal gains has negative consequences, and it has been described in Nigeria as an unethical practice that supports inefficiency, ineffectiveness, and low productivity, as it is characterized by decreased job performance leading to organizational jeopardy. ${ }^{54}$

The study also reveals that the respondents do not receive paid study leave even though they are expected to pursue postgraduate education. In essence, they have to sponsor their education. This further depletes their family income. The implication is that the respondents 
combine schooling with work and family responsibilities, as there is no incentive to embark on postgraduate studies on a full-time basis.

From the findings, overtime and shift duties interfere with the family needs of the respondents. This is because such duties further reduce the time that the respondents spend at home. The unique work experience of librarians arising from the incidence of inflexible work schedule has been highlighted as among the major barriers to the work-life balance of librarians.

Finally, the results on the strategies that could enhance work-life balance among female academic librarians reveal that all the outlined strategies are considered worthwhile. However, out of the strategies, getting more support from spouse, living at close proximity to work location, cancellation of shift duties, and cancellation of overtime duties received the highest mean scores, indicating that they are considered the most important strategies. Flexible work hours, small work week, job sharing, family leave programs, and onsite childcare and financial rewards are among the factors found to enhance work-life balance. ${ }^{55}$ Also family support and outsourcing of housework are equally worthwhile strategies. ${ }^{56}$

\section{Conclusion}

There is no doubt that academic librarians are important in the day-to-day operations of any academic library. Given that the preponderance of academic librarians is female, many of whom are married, the role they play in the success of any academic library cannot be overemphasized. However, their multiple roles as wives and employees who have obligations to both their families and employer often put a strain on them. Not only do academic librarians carry out the daily activities of libraries, but they are also required to perform their academic duties such as research and publishing for career progression.

This study described the perception of work-life balance among married female academic librarians in five university libraries in South East Nigeria. The results revealed that the respondents had a positive perception of work-life balance on both the family and organizational factor levels. However, the perception was higher on the organizational factor level than the family factor level.

While the findings of the study suggest that the married academic librarians perceive work-life balance positively at both the family and organizational levels, there is no doubt that there is still some room for improvement. It is important that university administrators understand and take into consideration the unique nature of academic librarians' jobs. Like the faculty members, some flexibility should be built into the schedules of academic librarians to enable them to cope with the requirements of academic status and their daily library activities. Also, the matter of overtime, shift, and weekend duties should be revisited, given the possibilities that are inherent in application of ICT in library operations.

Given the obvious dissatisfaction with remuneration, and the added burden of unfunded academic studies, university administrators are enjoined to pay holistic attention to this issue. Where the issues that affect the work-life balance of employees are not addressed, academic librarians, especially the married females, will resort to using coping strategies such as abandonment of duty post to run errands for their personal gains. This will be counterproductive. To that extent, practices and policies such as flexible work schedule, cancellation of overtime and shift duties, and better remuneration that can help employees to achieve better work-life balance should be implemented to encourage them to give quality job performance capable of satisfying their users. 


\section{Notes}

1. Promise Ifeoma Ilo, "Managing Stress among Librarians in Selected University Libraries in Ogun State Nigeria," Library Philosophy and Practice (e-journal) Paper 134 (2016), available from http://digitalcommons.unl. edu/libphilprac/1343.

2. D. Paton, D. Jackson, and P. Johnston, "Work Attitudes and Values," in Organizational Psychology in Australia and New Zealand, eds. M. O'Driscoll, P. Taylor, and T. Kalliath (Victoria, Australia: Oxford University Press, 2003), 129-49.

3. M.A. Omoniwa, "Twenty Years of Academic Status (1983-2003) for Librarians in Ahmadu Bello University Library System," Nigerian Librarie 37, no. 1 (2003): 60-66.

4. Romyna A. Rendon, "Work-Life Balance among Working Married Women: What Social Workers Need to Know," Electronic Theses, Projects, and Dissertations 374 (2016), https://scholarworks.lib.csusb.edu/etd/374.

5. Tamara Townsend and Kimberley Bugg, "Putting Work Life Balance into Practice: Policy Implications for Academic Librarians," Library Leadership \& Management 32, no. 3 (2018): 1-30, https://api.semanticscholar.org/ CorpusID:169555476.

6. Townsend and Bugg, "Putting Work Life Balance into Practice," 1-30.

7. Townsend and Bugg, "Putting Work Life Balance into Practice," 1-30.

8. Kelly Ward and Lisa Wolf-Wendel, "Academic Mothers: Exploring Disciplinary Perspectives," Innovative Higher Education 40, no. 1 (2015): 19-35, doi:10.1007/s10755-014- 9293-4.

9. C. Epei, "Strategies for Work-Family Balance and Preferences for Work Policies in Lagos Metropolis" (paper presented at the 3rd Colloquium of the Network of African Family Scholars, Nairobi, 2009).

10. Dawn S. Carlson and Michele K. Kacmar, "Work-Family Conflict in the Organization: Do Life Role Values Make a Difference?" J Manage 26 (2000): 1031-54.

11. N. Krishna Reddy et al., "Work-Life Balance among Married Women Employees," Indian Journal of Psychological Medicine 32, no. 2 (2010): 112-18, doi:10.4103/0253-7176.78508.

12. David Clutterbuck, Managing Work-life Balance: A Guide for Human Resource in Achieving Organizational and Individual Change (2003).

13. M.L. Reddy and P.M. Reddy, "Empirical Evidence on Work-life Balance in the Banking Sector," Asian Academic Research: Journal of Social Science and Humanities 1, no. 6 (2012): 1-7.

14. Monique Valcour, "Work-Based Resources as Moderators of the Relationship between Work Hours and Satisfaction with Work-Family Balance," Journal of Applied Psychology 92 (2007): 1512-23.

15. Diane M. Houston and Julie A. Waumsley, Attitudes to Flexible Working and Family Life (New York, NY: JRF Policy Press, 2003).

16. Rangarajan Balaji, "Work Life Balance of Women Employees," International Journal of Innovative Research in Science, Engineering and Technology 3, no. 10 (2014): 16840-43, available at IJIRSET www.ijirset.com.

17. Justina N. Ekere and Cyprian I. Ugwu, "Influence of Age, Gender and Working Experience on Librarians' Job Satisfaction in University Libraries in Nigeria," Journal of Information and Knowledge Management 2, no. 1 (2011): 1-18.

18. Quinn Galbraith, Leanna Fry, and Melissa Garrison, "The Impact of Faculty Status and Gender on Employee Well-being in Academic Libraries," College \& Research Libraries 15 (2016): 71-86, doi:10.5860/crl.77.1.71.

19. Galbraith, Fry, and Garrison, "The Impact of Faculty Status and Gender on Employee Well-being in Academic Libraries."

20. Townsend and Bugg, "Putting Work Life Balance into Practice."

21. Rendon, "Work-Life Balance among Working Married Women."

22. John Leaptrott and Michael J. McDonald, "The Differential Effect of Gender on the Way Conflict between Work and Family Roles Affect Managers' Reliance on Information Sources in Dealing with Significant Workplace Events," Journal of Organizational Culture, Communications and Conflict 15, no. 2 (2011): 1-30.

23. Dawn S. Carlson and Michelle K. Kacmar, “Work-family Conflict in the Organization: Do Life Role Values Make a Difference?" Journal of Management 5 (2000): 1031-54.

24. P. Kavitha, V. Kavitha, and P. Arulmurugan, "Role of Stress among Women Employees Forming Majority Workforce at IT Sector in Chennai and Coimbatore, Tier I and Tier II Centres," Sona Global Management Review 6, no. 3 (2012): 1-10.

25. Reddy, "Empirical Evidence on Work-life Balance in the Banking Sector."

26. Ayotunde Adebayo, "Work-Life Balance among Academic Staff of the University of Lagos," Makerere Journal of Higher Education 8, no. 2 (2016): 153-64, doi:10.4314/majohe.v8i2.6.

27. Una Byrne, "Work-Life Balance: Why Are We Talking about It All?" Business Information Review 22, no.1 
(2005): 53-59.

28. M.I. Muthukumar, R. Savitha, and P. Kannadas, "Work Life Balance," Global Journal of Finance and Management 6, no. 9 (2014): 827-32, available from www.ripublication.com.

29. Townsend and Bugg, "Putting Work Life Balance into Practice."

30. Shobha Sundaresan, "Work-Life Balance: Implications for Working Women," OIDA International Journal of Sustainable Development 7, no. 7 (2014): 93-102, available at https://papers.ssrn.com/.

31. Life Balance: Multidisciplinary Theories and Research, eds. Kathleen Matuska and Charles Christiansen (Bethesda, MD: AOTA Press/Slac, 2009).

32. Rendon, "Work-Life Balance among Working Married Women."

33. IProject, "Improving the Efficiency and Productivity of Nigeria Civil Service" (2020), available at https:// iproject.com.ng/public-administration/improving-the-efficiency-and-productivity-of-nigeria-civil-service/index. html.

34. Ebere N. Anyaoku, "Demographic Determinants of Quality of Work Life of Librarians Working in Nigeria," International Journal of Advanced Library and Information Science Volume 4, no. 1 (2016): 312-23, doi:10.23953/ cloud.ijalis.21.

35. Daniel Ampem Darko-Asumadu, Solomon Sika-Bright, and Brempong Osei-Tutu, "The Influence of WorkLife Balance on Employees' Commitment among Bankers in Accra," African Journal of Social Work 8, no. 1 (2018): 47.

36. Galbraith, Fry, and Garrison, "The Impact of Faculty Status and Gender on Employee Well-being in Academic Libraries."

37. Townsend and Bugg, "Putting Work Life Balance into Practice."

38. P. Kavitha, V. Kavitha, and P. Arulmurugan, "Role of Stress among Women Employees Forming Majority Workforce at IT Sector in Chennai and Coimbatore, Tier I and Tier II Centres," Sona Global Management Review 6, no. 3 (2012): 1-10.

39. Kavitha, Kavitha, and Arulmurugan, "Role of Stress among Women Employees Forming Majority Workforce at IT Sector in Chennai and Coimbatore, Tier I and Tier II Centres."

40. Grover Sweety, "A Comparative Study of Work Life Balance of Urban Female and Rural Female Doctors Engaged in Private Practice," International Journal of Business Quantitative Economics and Applied Management Research 3, no. 4 (2016): 2349-5677.

41. Kavitha, Kavitha, and Arulmurugan, "Role of Stress Among Women Employees Forming Majority Workforce at IT Sector in Chennai and Coimbatore, Tier I and Tier II Centres."

42. Anju Sigroha, "Impact of Work Life Balance on Working Women: A Comparative Analysis," Business $\mathcal{E}$ Management Review 5, no. 3 (Nov. 2014): 22-30.

43. Townsend and Bugg, "Putting Work Life Balance into Practice."

44. Vijaya Mani, "Work Life Balance and Women Professionals," Global Journal of Management and Business Research Interdisciplinary 13, no. 5 (2013): 35-41.

45. Gayatri Pradhan, Work-Life Balance among Working Women: A Cross-cultural Review (Bangalore, India: Institute for Social and Economic Change, 2016).

46. Townsend and Bugg, "Putting Work Life Balance into Practice."

47. "Questionnaire on an Empirical Analysis of Work-Life Balance on Women Employees: A Study with Reference to Banking Sector," available at https://shodhganga.inflibnet.ac.in/bitstream/10603/38349/13/13_quesionnare. pdf (accessed 26 November 2018).

48. Mohsen Tavakol and Reg Dennick, "Making Sense of Cronbach's Alpha," International Journal of Medical Education 2 (2011): 53-55, doi:10.5116/ijme.Adfb.8dfd.

49. Sigroha, "Impact of Work Life Balance on Working Women: A Comparative Analysis."

50. Pradhan, Work-Life Balance among Working Women: A Cross-cultural Review.

51. Reddy et al., "Work-Life balance among Married Women Employees."

52. Reddy et al., "Work-Life balance among Married Women Employees."

53. Epei, "Strategies for Work-Family Balance and Preferences for Work Policies in Lagos Metropolis."

54. IProject, "Improving the Efficiency and Productivity of Nigeria Civil Service."

55. Life Balance, eds. Matuska and Christiansen.

56. Townsend and Bugg, "Putting Work Life Balance into Practice." 